\title{
Multiple Complete Digest Restriction Fragment Mapping
}

National Cancer Institute

\section{Source}

National Cancer Institute. Multiple Complete Digest Restriction Fragment Mapping. NCI Thesaurus. Code C116160.

A DNA mapping technique based on complete restriction enzyme digestion of a set of overlapping clones that provides highly redundant coverage of the mapping target. 